\title{
Nigeria's cocoa exports: a gravity model approach
}

\section{Nazir Muhammad Abdullahi' ${ }^{1,2}$ (D) Saleh Shahriar ${ }^{3}$ Sokvibol Kea $^{1}$ Aminu Muhammad Abdullahi² (D) Qiangqiang Zhang ${ }^{1}$ (D) Xuexi Huo ${ }^{1^{*}}$}

${ }^{1}$ College of Economics and Management, Northwest A\&F University, 712100 Shaanxi, China. E-mail: xuexihuo@nwafu.edu.cn. ${ }^{*}$ Corresponding author.

${ }^{2}$ School of Rural Technology and Enterprenuership Development, Kano State Polytechnic, Kano, Nigeria.

${ }^{3}$ School of Humanities and Social Sciences, North South University, Bashundhara, Dhaka, Bangladesh.

ABSTRACT: What are the major factors affecting Nigeria's cocoa export flows? In answering this question, the authors suggest a commodityspecific gravity model with three different analytical approaches, (the Heckman Sample Selection Model, the Generalised Least Square, and the Poisson Pseudo Maximum Likelihood), based on a period of 24 years of panel data for Nigeria and it's 36 importing partners to estimate the models. The results showed that GDP, exchange rate policy, WTO, EU, and colonial link are positively associated with the Nigerian cocoa export flows. Further, the negative impact of the GDP per capita, landlocked, distance, AU, and ECOWAS are observed. The need for the expansion of exports to the trading partners, especially the EU members (Netherlands, Germany, France, United Kingdom, Belgium, Spain, etc.), Canada, Malaysia, and the USA is particularly highlighted. These results are important for the formulation of future trade policy that could boost up the Nigerian cocoa exports. This would eventually contribute to the diversification of the Nigerian exports and also enhance the country's foreign earnings.

Key words: cocoa exports, Heckman section model, Generalized least square (GLS), Poisson pseudo-maximum-likelihood (PPML), panel data.

Exportações de cacau da Nigéria: uma abordagem do modelo gravitacional

RESUMO: Quais são os principais fatores que afetam os fluxos de exportação de cacau da Nigéria? Ao responder a esta pergunta, os autores sugerem um modelo de gravidade especifica de mercadoria com três abordagens analíticas diferentes (o Modelo de Seleção de Amostras de Heckman, o Mínimo Quadrado Generalizado e a Pseudo Máxima Verossimilhança de Poisson), com base em um periodo de 24 anos de dados em painel para a Nigéria e seus parceiros importadores para estimar os modelos. Os resultados mostram que o PIB, a política cambial, a OMC, a UE e a ligação colonial estão positivamente associados aos fluxos de exportação de cacau da Nigéria. Além disso, é observado o impacto negativo do PIB per capita, sem litoral, distância, UA e CEDEAO. Destaca-se a necessidade de ampliação das exportações para os parceiros comerciais, especialmente os membros da UE (Holanda, Alemanha, França, Reino Unido, Bélgica, Espanha, etc.), Canadá, Malásia e Estados Unidos. Esses resultados são importantes para a formulação de uma política comercial futura que possa impulsionar as exportações de cacau nigeriano. Isso acabaria por contribuir para a diversificação das exportações nigerianas e também aumentar as receitas externas do pais.

Palavras-chave: exportações de cacau nigeriano, modelo de seção de Heckman, mínimo quadrado generalizado (GLS), Poisson pseudomáxima verossimilhança (PPML), dados em painel.

\section{INTRODUCTION}

Nigeria is an agrarian country where agricultural activities are the primary source of economic survivals and livelihoods. Although, the country's agricultural Gross Domestic Product (GDP) and employment have substantially fallen from $37 \%$ and $47 \%$ in 2002 to $22 \%$ and $36 \%$ in 2019 , the values are of huge significance to date (WORLD BANK, 2020). Among all the major agricultural products, cocoa is the single commodity contributing significantly to the agricultural revenue. Cocoa is such an important agricultural product that has occupied a central place in the economic policy processes (OSABOHIEN et al., 2019). Cocoa is a leading commodity of foreign exchange from nonoil exports (FAMUYIWA et al., 2014). In 2018, the country exported 321.99 thousand tons of cocoa worth $\$ 657.61$ million to the global market (FAOSTAT, 2020). 
The sector is encountering a plethora of challenges and problems including the climate change, small farm holding, technological modernization, access to finance, and pest and diseases (UWAGBOE et al., 2017). Nigeria is the second-largest producer and exporter of cocoa in the 1960s and accounted for more than $15 \%$ of the global cocoa output (VERTER, 2016). At that time, the agricultural exports accounted for over $75 \%$ of total annual merchandise exports. Nevertheless, these problems dated back to a decade after the country got its independence with a growing lack of food supply, increasing food prices, and decreasing foreign exchange earnings from agricultural exports, and increasing food import bills. The condition further deteriorated due to the adverse effects of the civil war, government policies (fiscal and monetary), frequent change of government (from a military regime to democracy and from one political party to another), corruption (FAGBADEBO, 2020), terrorism, and severe droughts. The issue of "oil boom" created both opportunities and distortions in the economy and increased the degree of movement of labour from agriculture to non-agriculture (OSABUOHIEN, 2014).

Given the significance of agriculture in general and cocoa in particular to the Nigerian economy, the Federal Republic of Nigeria (FRN) makes it her top mission to diversify its economy and proactively decrease its vulnerability, after the country has slipped into recession in 2016 (MBNP, 2017). The FRN has suffered recently with the drop in the price of crude oil in the international market. Therefore, the country embarked on several agricultural promotion measures required to revive the economy and stop the decreasing tide (ADELEYE et al., 2020). It contains an economic policy document, called the Economic Recovery and Growth Plan (ERGP) in 2017. The document emphasises the needs to boost cocoa production and exports. Therefore, the government has again paid its attention to cocoa cultivation and it still has the available land and climate to boost the output of cocoa, increase the volume of export as well as helping the economy recover (NEPC, 2017).

Foreign trade is a significant determinant of the economic growth in developing countries including Nigeria (ATIF et al., 2016; ALI et al., 2020). Agricultural exports are likely to have a positive impact on the economy of a developing nation (SHAFIULLAH et al., 2017). The income generation from cocoa export might contribute to the growth of the Nigerian economy and reduce its overdependence on the exports of oil.
To the best of the authors' knowledge, there is no significant research on Nigeria's cocoa exports using the gravity model. However, a limited number of studies are reported regarding the Nigerian trade (ALIYU \& BAWA, 2015; OLADIPUPO \& ADEDOYIN, 2019), cocoa exports competitiveness (NWACHUKWU et al., 2010) and political economy of cocoa (OLAIYA, 2016). It is thus apparent that there is a dearth of literature on the determinants of the Nigerian exports of cocoa.

Therefore, this study analyzed the major factors affecting the Nigerian agricultural export performance in the international market, with a reference to identifying the main factors influencing Nigerian cocoa export performance by an application of the panel data gravity model. Hence, the study contributed to the existing literature in several ways. First, it would fill the research gap on the determinants of the Nigerian cocoa exports by covering a total of 36 countries for a period of 24 years of panel data. The authors take into consideration the availability of data before selecting the period of the study. Second, our study is unique from previous studies in the sense that, it applies the gravity model by integrating numerous methods including, the Heckman selection models, the Generalized Least Square (GLS), and the Poisson Pseudo Maximum Likelihood (PPML). These methods were mainly applied independently in the existing literature. Third, the study would enrich the current literature on the commodity-specific gravity model of agricultural exports. Presently, there are some studies on the export determinants of product/agricultural commodities such as coffee (NSABIMANA \& TIRKASO, 2019), rice (BUI \& CHEN, 2015; KEA et al., 2019), coffee and rice (NGUYEN, 2020), soybeans (BOEREMA et al., 2016), wine (CASTILLO et al., 2016), poultry (ZHOU et al., 2019), meat (SHAHRIAR et al., 2019a), leather and textile (JORDAAN \& EITA, 2012; RAHMAN et al., 2019), creative goods (DONG \& TRUONG, 2019), and forest products (NASRULLAH et al., 2020). Lastly, this study provided new insights and allowed us to derive some policy implications about the development and sustainability of cocoa export in Nigeria.

\section{The shape of the Nigerian cocoa market}

Figure 1 illustrates the ranking of export destinations based on Nigeria's average export values of cocoa between 1995 and 2018. Nigeria's top ten cocoa export destinations are as follows: Netherlands (36.74\%), Germany (13.34\%), France (6.66\%), United Kingdom (6.15\%), Belgium (5.89\%), Spain 


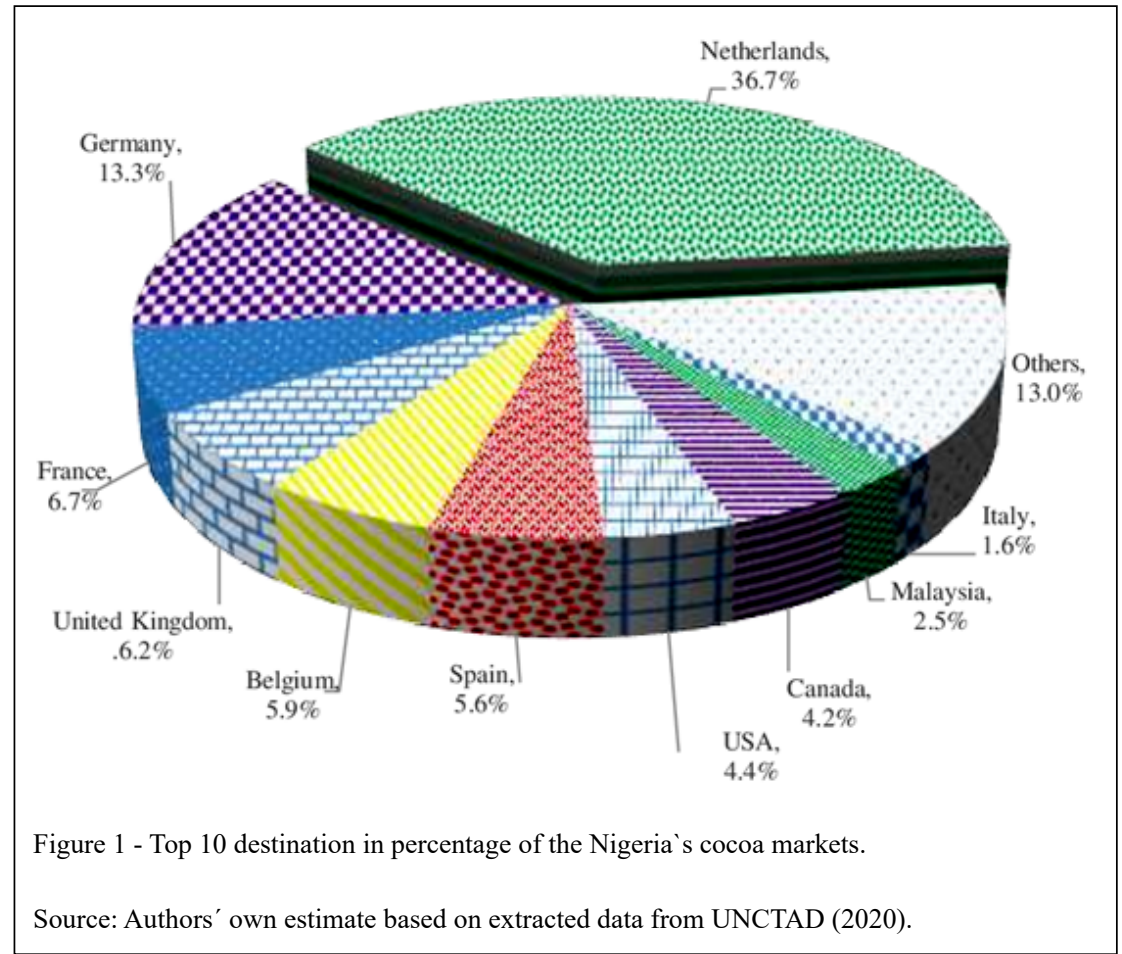

(5.64\%), USA (4.35\%), Canada (4.15\%), Malaysia $(2.48 \%)$, and Italy $(1.58 \%)$. The figure also shows that the export flow of Nigerian cocoa to those ten countries accounted for approximately $87 \%$ of Nigeria's total cocoa export flow to the global market. Similarly, during the study period, Nigeria accounted for cocoa import shares of Netherlands (8.28), Germany (8.39\%), France (5.72\%), United Kingdom (9.64\%), Belgium (8.54\%), Spain (9.21\%), USA (1.36\%), Canada (5.17\%), Malaysia (1.78\%), and Italy (3.13\%) (UNCTAD, 2020).

The European Union (EU) is the most significant market for Nigeria's cocoa exports. Netherlands, Germany, France, United Kingdom, and Belgium are the major destinations of Nigeria's cocoa in Europe. Figure 2 shows that the export flows from Nigeria to these five countries between 1995 and 2018 reached the amount of $\$ 329$ million annually, which accounted for about $69 \%$ of total Nigeria's cocoa market share.

\section{The state of the cocoa economy at a global scale}

The cocoa bean is one of the major cash crops in Africa, produced mostly for export purposes and the region accounts for more than $75 \%$ of the global cocoa (production and exports) which makes the regions a global phenomenon (WESSEL
\& QUIST-WESSEL, 2015; ICCO, 2017). Figure 3 shows that the Ivory Coast and Ghana are the two largest producers and exporters of cocoa. In 2017, the production of these countries' reached 2.03 million tons and 893.60 thousand tons respectively. Indonesia and Nigeria which occupied third and fourth positions exported 659.78 and 324.39 thousand tons of cocoa respectively. Four countries out of the top five producers are from Africa. Similarly, three out of the five largest producers are from the same region in Africa; i.e. West Africa, revealing that this region is the most important baskets of the global cocoa market. Cameroon is the largest producer in Central Africa and fifth in the world, however, Cameroon ranked seventh among the largest exporters. The country exported 260.01 thousand tons of cocoa Figure 3).

\section{LITERATURE REVIEW}

\section{The gravity models}

The gravity model is one of the most popular empirical tools for analysis in international trade studies (MA'TYA'S, 1998; ANDERSON \& Wincoop, 2003). Tinbergen became the first person to propose the use of the gravity equation in international trade studies (TINBERGEN, 1962), while

Ciência Rural, v.51, n.11, 2021. 


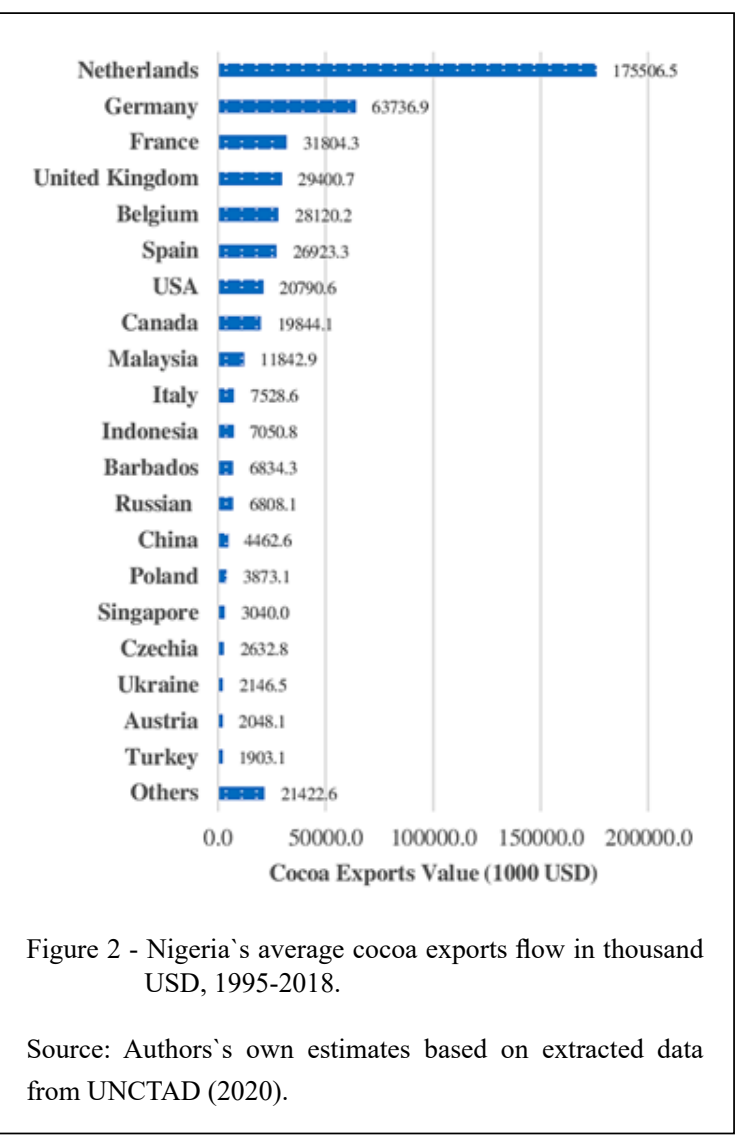

ANDERSON (1979) comprehensively examined the model with the expectations that bilateral trade between two countries is positively determined by each country's GDP, and negatively by their distance apart. The gravity model for cocoa exports in linear form can be mathematically expressed as follows:

$$
\ln \left(X_{i j}\right)=\beta_{0}+\beta_{1} \ln \left(Y_{i}\right)+\beta_{2} \ln \left(Y_{j}\right)+\beta_{3} \ln \left(D i s_{i j}\right)
$$

Where, "Xij" denotes the value of cocoa exports from Nigeria to its trading partners. " $Y i$ " is the GDP of Nigeria and " $Y j$ " denotes the GDP of Nigerian trading partner. "Dis $i_{i j}$ " stands for the distance between Nigeria and trading partner. " $\mathrm{j}$ " = 1 . . ..36 is for trading partners and $t=1995$...2018 annual series. "In" stands for a natural log.

Several researchers used the gravity model in different forms. For example, the gravity model was derived for the first time by ANDERSON (1979) through the application of the product differentiation model, which adopts constant elasticity of replacement (CER) desired functions for all countries or identical Cobb-Douglas and weakly separable utility functions among traded and nontraded goods. Anderson analyses at the cumulative level, HELPMAN \& KRUGMAN (1987) justify the gravity model by differentiated product market and assuming increasing returns to scale. Based on 18 industrial countries, HELPMAN \& KRUGMAN also recognized a linkage between the gravity model and the monopolistic competition model.

BERGSTRAND (1989); BERGSTRAND

(1990) previously examined the microeconomic foundations of trade through monopolistic competition models. He claimed that a gravity model is a summarized form of a general equilibrium of demand and supply systems. DEARDORFF (1998) develops it from a Heckscher-Ohlin (H-O) viewpoint, and showed that this model was reliable with a large number of trade models such as the Ricardian model, $\mathrm{H}-\mathrm{O}$ model, increasing returns to scales, and so on. MA'TYA'S (1998) suggested incorporating the trading bloc dummy variable(s), and time precise effects into the specification of the gravity models without dealing with the issue of trading potentials. EGGER (2002) proposed ideas into the difficulties related to the in-sample forecast of trade potentials based on panel data and into the selection of the adequate estimation method.

Excluding multilateral resistance factors in the prior gravity model, ANDERSON \& Wincoop (2003) argued that the estimation could lead to biased inferences. The authors developed an improved gravity model by adding multiple resistance factors and applied it to resolve the famous "border puzzle." HELPMAN et al. (2008) derive the improved gravity equation of ANDERSON \& Wincoop (2003) in two ways to address the lack of trade "Zeros trade" flows problem. First, it accounts for asymmetries between the volume of exports from $i$ to $j$ and the volume of exports from $j$ to i. Second, it accounts for fixed trade and firm heterogeneity costs; and therefore, forecasts an extensive margin for trade flows. CHANEY (2008) argued that when the cost of transportation changes, not only does each exporter change the size of its exports (the intensive margin), but the set of exporters changes as well (the extensive margin). He also introduced firm heterogeneity in a simple model of international trade. Several prior studies showed how the gravity model has developed itself as a "workhorse" for the study of international trade (HEAD \& MAYER, 2014; SHEPHERD, 2019). YOTOV et al. (2016) introduced the structural gravity model as an advanced guide to trade policy analysis, though CHANEY (2018) provided an in-depth description of the gravity equation in international 


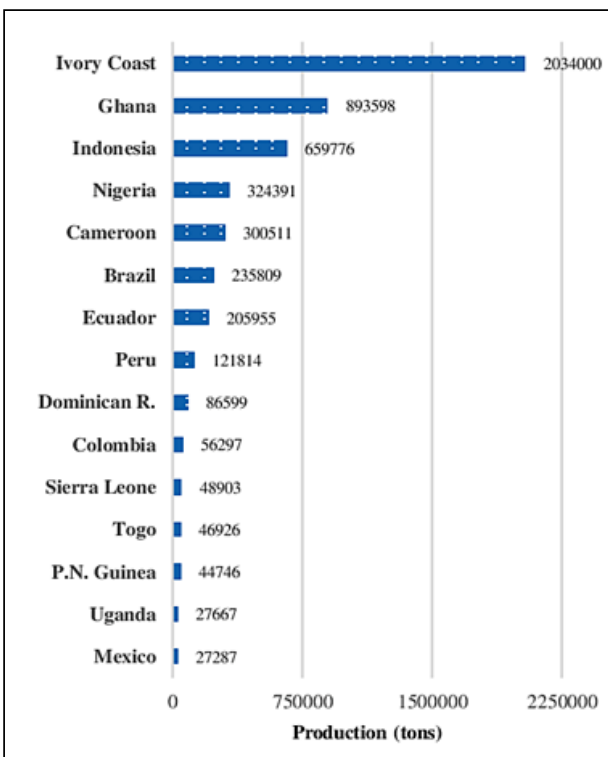

(A) Cocoa production quantity

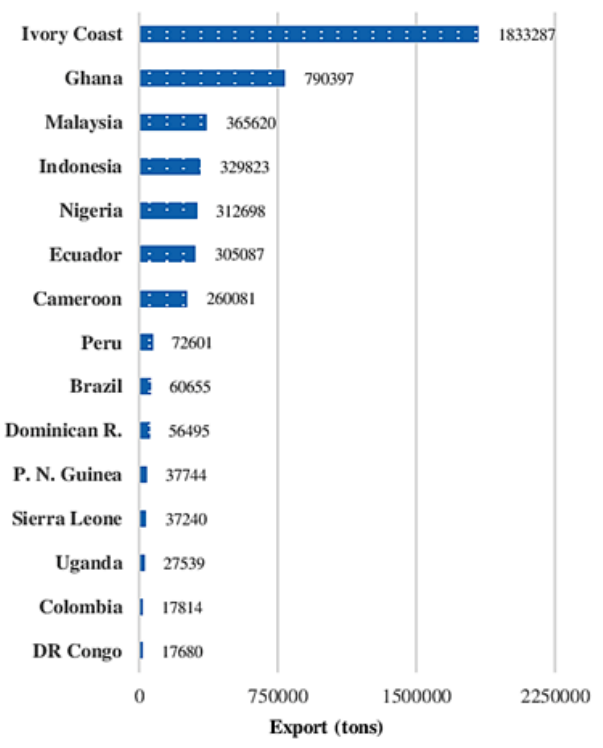

(B) Cocoa export quantity

Figure 3 - The world's top cocoa producers and exporters in 2017.

Source: Author's own estimates based on extracted data from FAOSTAT (2020). Note: The export quantity consist of the total of four different kinds of cocoa (cocoa bean, cocoa butter, cocoa paste and cocoa powder), "Dominica R." = Dominica Republic, "P.N. Guinea" = Papua New Guinea, "USA" = United States.

trade. SHAHRIAR et al. (2019b) explained the theoretical dimensions of the trade gravity model.

Several studies used the commodityspecific to determine trade flows. Only a few studies used the Heckman model, GLS and PPML in a single study. For instance, KEA et al. (2019) using these approaches study the dynamic panel for the Cambodian rice exports between 1996 and 2018. The results disclose that the historical ties, exchange rate policy, and the agricultural land reform promote the Cambodian rice export. The study suggested that as a macroeconomic issue and resistance factor, the economic recession hinders the export flows, and needs more exceptional considerations. In the same direction, SHAHRIAR et al. (2019a) have provided a case study of the Chinese meat industry for the period 1996-2016 and revealed that GDP, exchange rate, common language, and country land area affect the Chinese pork export flows. Similarly, the Belt and Road Initiative and the WTO membership, common border are positively associated with pork export flows. The study concluded that the Chinese government could enhance the pork export system with its bordering countries.
BRAHA et al. (2017) used the gravity model with the PPML panel data and reported that agricultural export flow grows with increasing economic size, indicating a higher impact of importer's absorbing potential compared to Albania's productive potential. Also, the bilateral distance, common border, and common language have a negative impact on export flows. Albania has a vast potential to become a competitive player in international markets if supportive measures are fixed in increasing the productivity of labour-intensive agricultural sectors. DADAKAS et al. (2020) explored the UAE's trade potential and indicated that the economic size of the UAE and its trading partner, common language and colonial link stimulate the country's export. Whereas, distance has proven to be an obstacle for UAE's trade. Similarly, HOANG et al. (2020) also applied the PPML to study the factors affecting trade between Taiwan and ASEAN countries from 2000-2017.

In the Nigerian context, ALIYU \& BAWA (2015) investigated the factors affecting Nigeria's trade flow for the period of 1999-2012. Using the fixed effects and random effects, the results showed that market size and price index of destination countries 
positively drive trade flows in Nigeria. The results confirmed that Nigeria's exports follow the Linder hypothesis. Using the fixed effects, OLADIPUPO \& ADEDOYIN (2019) study the factors affecting the bilateral trade flows of Nigeria for a panel data of 16 trading partners between 2000 and 2016. No study is thus available on the determinants of Nigeria's cocoa export using the gravity model. Therefore, we aimed to fill this gap in the current literature.

In light of the above discussions, it is clear that the previous studies provided the theoretical and empirical basis for the gravity model that are in line with some analytical approaches such as the Ricardian model, H-O model, monopolistic competition, and the "new trade" theory.

The generalised gravity model of the Nigerian cocoa exports

In this study, the gravity model of Nigerian cocoa exports can be expressed as follows:

$$
\operatorname{lnCocoaExp}_{i j t}
$$

$$
\begin{aligned}
& =\alpha+\beta_{1} \ln \left(G D P_{i t} \cdot G D P_{j t}\right)+\beta_{2} \ln \left(p c G D P_{i t} \cdot p c G D P_{j t}\right) \\
& +\beta_{3} \ln \left(\text { dpcGDP }_{i t} \cdot \text { dpcGDP }_{j t}\right)+\beta_{4} \ln \left(\text { Dis }_{i j}\right)+\beta_{5} \ln \left(E x c_{i j}\right) \\
& +\gamma_{1}\left(\text { landlocked }_{j}\right)+\gamma_{2}\left(\text { border }_{i j}\right)+\gamma_{3}\left(\text { language }_{i j}\right)+\gamma_{4}\left(\text { WTO }_{j t}\right) \\
& +\gamma_{5}\left(E U_{j t}\right)+\gamma_{6}\left(A U_{j t}\right)+\varepsilon_{i j t}
\end{aligned}
$$

Where as, the $\ln ($.$) denotes the logarithm$ form. $\alpha$ indicates the intercept, whereas, $\beta_{\mathrm{s}}, \gamma_{\mathrm{s}}$ are the estimated coefficients and $\varepsilon_{\mathrm{ijt}}$ denotes the stochastic error term.

\section{Lack of trade or zero trade problem}

The lack of trade problems occurs in some periods of time when some pair of countries did not trade with each other for some reason. In the absence of trade between $\mathrm{i}$ and $\mathrm{j}$ countries, the gravity equation becomes problematic as the trade value of $[\log (0)$ is undefined]. Therefore, in order to overcome this problem we employed the most common approaches used in gravity literature; the PPML method suggested by (SANTOS SILVA \& TENREYRO, 2006; SANTOS SILVA \& TENREYRO, 2010) and the Heckman Selection model (HECKMAN, 1979). Though, some researchers such as BURGER et al. (2009) and MARTÍNEZ-ZARZOSO (2011) criticized the PPML estimator suggesting that results are biased in the presence of zero trade when combined with heteroscedasticity and can lead to inconsistent of the estimates. However, some researchers such as MARTIN \& PHAM (2020) and SANTOS SILVA \& TENREYRO (2011) recommended that the PPML estimator is not biased by extra zeros and it is consistent when high variability exists in the data set. The PPML allows the estimation of a gravity model which includes zeros and the dependent variable will not take log form (SANTOS SILVA \& TENREYRO, 2006). In the case of Nigerian cocoa, the PPML model can be written as follows:

$\operatorname{CocoaExp}_{i j t}=\alpha+\beta_{1} \ln \left(G D P_{i t} \cdot G D P_{j t}\right)+\beta_{2} \ln \left(p_{c} G D P_{i t} \cdot p c G D P_{j t}\right)$

$$
\begin{aligned}
& +\beta_{3} \ln \left(\text { dpcGDP }_{i t} . d p c G D P_{j t}\right)+\beta_{4} \ln \left(\text { Dis }_{i j}\right)+\beta_{5} \ln \left(\text { Exc }_{i j}\right) \\
& +\gamma_{1}\left(\text { landlocked }_{j}\right)+\gamma_{2}\left(\text { border }_{i j}\right)+\gamma_{3}\left(\text { language }_{i j}\right)+\gamma_{4}\left(\text { WTO }_{j t}\right) \\
& +\gamma_{5}\left(E U_{j t}\right)+\gamma_{6}\left(A U_{j t}\right)+\varepsilon_{i j t}
\end{aligned}
$$

The Heckman selection model comprises two different equations, namely, sample selection (eq. 4,5 ) and outcome (eq. 6). The sample selection for Nigerian cocoa export can be written as follows:

$\mathrm{t}_{\mathrm{ijt}}^{*}=\eta^{\prime} \mathrm{Z}_{\mathrm{ijt}}+\mu_{\mathrm{ijt}}$

Whereas, $\mathrm{t}_{\mathrm{ijt}}^{*}$ denotes latent variable and it is not observed but we do observe if countries trade or not, such that $t_{\mathrm{ijt}}^{*}=1$ if $\mathrm{t}_{\mathrm{ijt}}^{*}>0$ and $\mathrm{t}_{\mathrm{ijt}}^{*}=1$ if $\mathrm{t}_{\mathrm{ijt}}^{*}=0$ and $\mathrm{Z}_{\mathrm{ijt}}$ denotes a vector variable that affects $\mathrm{t}_{\mathrm{ijt}}^{*} \cdot \mu_{\mathrm{ijt}}$ denotes the error term. However, there are some variables that are not in the model but they might affect the $t_{\mathrm{ijt}}^{*}$ in this study. In addition to the other independent variables, the study has also added some dummies to find out the impact of the landlocked country, common language, common border, and the WTO, AU, and EU membership on cocoa exports. Thus, we expect their coefficients to have different signs (Table 2). The details of the equation (4) can be written as follows:

Selection Equation:

$$
\begin{aligned}
& t_{i j t}^{*}=\eta_{0}+\eta_{1} \ln \left(G D P_{i t} \cdot G D P_{j t}\right)+\eta_{2} \ln \left(p c G D P_{i t} \cdot p c G D P_{j t}\right) \\
& +\eta_{3} \ln \left(\mathrm{dpc} G D P_{i t} \cdot d p c G D P_{j t}\right)+\eta_{4} \ln \left(\text { Dis }_{i j}\right)+\eta_{5} \ln \left(E x c_{i j}\right) \\
& +\eta_{6}\left(\text { landlocked }_{j}\right)+\eta_{7}\left(\text { border }_{i j}\right)+\eta_{8}\left(\text { language }_{i j}\right)+\eta_{9}\left(\text { WTO }_{j t}\right) \\
& +\gamma \eta_{10}\left(E U_{j t}\right)+\eta_{11}\left(A U_{j t}\right)+\mu_{i j t}
\end{aligned}
$$

Outcome Equation:

$$
\begin{aligned}
& t_{i j t}^{*}=\eta_{0}+\eta_{1} \ln \left(G D P_{i t} \cdot G D P_{j t}\right)+\eta_{2} \ln \left(\text { pcGDP }_{i t} \cdot p c G D P_{j t}\right) \\
& +\eta_{3} \ln \left(\operatorname{dpc} G D P_{i t} \cdot \text { dpcGDP }_{j t}\right)+\eta_{4} \ln \left(\text { Dis }_{i j}\right)+\eta_{5} \ln \left(\text { Exc }_{i j}\right) \\
& +\eta_{6}\left(\text { landlocked }_{j}\right)+\eta_{7}\left(\text { border }_{i j}\right)+\eta_{8}\left(\text { language }_{i j}\right)+\eta_{9}\left(\text { WTO }_{j t}\right) \\
& +\gamma \eta_{10}\left(E U_{j t}\right)+\eta_{11}\left(A U_{j t}\right)+\eta_{12}\left(\text { Ecowas }_{j t}\right)+\eta_{13}\left(\text { colony }_{i j}\right) \\
& +\eta_{14}\left(\text { asia }_{j}\right)+\mu_{i j t}
\end{aligned}
$$

The selection of the independent variables is a difficult task in econometrics. According to AMEMIYA (1980), the selection of regression analysts should be based on economic-theory considerations along with statistical reasoning. The omitted variables might lead to biased conclusions in the estimations of the model (WOOLDRIDGE, 2002). 
There are two main sources of misspecifications of the model which include: (1) invalid assumptions on the distribution term and (2) incorrect functional form. Consequently, the selection of regressors should be taken into consideration and the correct specification of the model, function form (BERA \& JARQUE, 1982). Based on the above guidelines and instructions, we relied on the trade theories and prior empirical studies in selecting the relevant variables for the specification of the empirical gravity model of the Nigerian cocoa exports. In this study, we employed three different methods of estimation to confirm the robustness of the findings. Thus, the models we use could solve the problems of hetroscedasticity, multicollinearity, and serially correlated errors (SANTOS SILVA \& TENREYRO, 2006; HAQ et al., 2013).

\section{Sampling size and data sources}

One of the main benefits of the panel data is to get rid of some biases and disadvantages arising out of the time series and cross-sectional estimations (BALTAGI et al., 2018; SHEPHERD, 2019). Following the literature, we applied the panel data models to estimate the gravity equations of the Nigerian cocoa exports. The sample of this study comprised Nigeria and its 36 cocoa importing partners over 24 years, covering from 1995 to 2018. These 36 countries are selected based on Nigeria's annual average cocoa export value. During the period, the export value of Nigeria's cocoa to those 36 destinations accounted for $95.45 \%$ of the total cocoa exported value of Nigeria. Therefore, the dataset of this study consist of a total observation of $864(\mathrm{~N}=36 \times \mathrm{T}=24)$. The list of the countries engaged in cocoa trade with Nigeria included in the sample is shown in table 1 . The data sources are mentioned in table 2 and 3 shows the descriptive statistics of the variables.

\section{RESULTS AND DISCUSSION}

Table 4 and 5 show the results estimated from the Heckman selection models, GLS, and PPML models respectively. In general, the three models are almost similar in terms of variables signs, coefficients, and statistical significance at conventional levels. In addition, to confirm the appropriateness of our baseline model (random effect/GLS), we have conducted a Hausman test. The result showed a p-value of 0.071 which indicated that we accept our null hypothesis that is the GLS is the appropriate model. These two tables showed the factors affecting Nigeria's cocoa exports. They are the GDP, per capita GDP, distance, exchange rate, landlocked of partner country j, common border, common language, WTO, EU, AU, ECOWAS membership of partner country $\mathrm{j}$, Asia and colonial link. Among these variables, we found eight key variables to be highly significant at a $1 \%$ level of significance, the variables include; $\left(G D P_{i t} G D P_{j t}\right)$, distance, exchange rate, landlocked, common border, WTO, EU, and AU membership. The coefficients of $\left(G D P_{i t} G D P_{j i}\right)$, exchange rate, WTO, EU, and border are positive whereas, the signs of distance and landlocked are negative.

The positive sign of $G D P_{i t} G D P_{j t}$, indicates that Nigeria has the potential to trade more of its cocoa with wealthier countries. This implied that holding other variables constant, a $1 \%$ increase in $G D P_{i t}$. $G D P_{j t}$, result in roughly a $0.33 \%$ increase in export volume. This finding is in line with prior studies such as ANH THU et al. (2019); LIU et al. (2020).

Although, the per capita income of Nigeria and its cocoa importing partners $\left(p c G D P_{i t} p c G D P_{j}\right)$ maintain it negative sign in all the models; however, we reported per capita income to be significant in GLS and PPML models with different significance levels $5 \%$ and $10 \%$ respectively. The negative sign

Table 1 - Sample economies and countries used in the study.

\begin{tabular}{|c|c|c|}
\hline Continents & Economies/Country & \#country \\
\hline Africa & Algeria, Benin, Cameroon, Ivory Coast, Gabon, Ghana Kenya, Niger, South Africa. & 9 \\
\hline America & Barbados, Canada, United States of America (USA) & 3 \\
\hline Asia \& Pacific & $\begin{array}{c}\text { Armenia, China (mainland), India, Indonesia, Malaysia, Japan, Russian Federation, Singapore, Turkey, } \\
\text { Viet Nam }\end{array}$ & 10 \\
\hline \multirow[t]{2}{*}{ Europe } & $\begin{array}{c}\text { Austria, Belgium, Bulgaria, Czechia, Estonia, France, Germany, Italy, Netherlands, Poland, Spain, } \\
\text { Switzerland, Ukraine, United Kingdom }\end{array}$ & 14 \\
\hline & Total number of countries used in this study & 36 \\
\hline
\end{tabular}

Source: Authors' own elaboration. Note: "No. of Country" = Number of country. 
Table 2 - Detail description of data sources, unit and expected sign of the variables.

\begin{tabular}{|c|c|c|c|c|}
\hline Variables & Description & Unit & Source of Data & Expected Sign \\
\hline $\operatorname{CocoaExp}_{i j t} / \ln \left(\operatorname{cocoaExp}_{i j t}\right)$ & Bilateral cocoa exports & Thousand USD & UNCTAD & \\
\hline $\ln \left(G D P_{i t} \cdot G D P_{j t}\right)$ & $\begin{array}{l}\text { Aggregate income of Nigeria } \\
\text { and its partners }\end{array}$ & Million USD & WDI & + \\
\hline $\ln \left(p c G D P_{i t} \cdot p c G D P_{j t}\right)$ & $\begin{array}{c}\text { Per capita GDP of Nigeria and } \\
\text { its partners }\end{array}$ & USD & WDI & + \\
\hline $\ln \left(d p c G D P_{i j t}\right)$ & Difference of per capita & USD & $\begin{array}{l}\text { Author's own } \\
\text { calculation }\end{array}$ & $+1-$ \\
\hline $\ln \left(E x c_{i j t}\right)$ & Bilateral exchange rate & Naira j/j's currency & UNCTAD & $+/-$ \\
\hline $\ln \left(\right.$ Distance $\left._{i j}\right)$ & $\begin{array}{c}\text { Distance between Abuja and } \\
\text { j's capital city }\end{array}$ & Kilometres & Distance calculator & - \\
\hline landlocked $_{j}$ & Landlocked country j & 0/1 Dummy & CEPII Database & - \\
\hline border $_{i j}$ & Common border with Nigeria & 0/1 Dummy & CEPII Database & $+1-$ \\
\hline language $_{i j}$ & $\begin{array}{c}\text { Share same official language } \\
\text { with Nigeria }\end{array}$ & 0/1 Dummy & CEPII Database & $+/-$ \\
\hline$E U m_{j}$ & EU membership & 0/1 Dummy & www.europa.eu & + \\
\hline Aum $_{j}$ & AU membership & 0/1 Dummy & www.au.int & $+/-$ \\
\hline$W_{T O m_{j}}$ & WTO membership & 0/1 Dummy & www.wto.org & + \\
\hline Ecowas $_{j}$ & Regional trade agreement & 0/1 Dummy & www.ecowas.int & - \\
\hline$a_{s i a}$ & Geographical location & 0/1 Dummy & CEPII Database & $+1-$ \\
\hline
\end{tabular}

Source: Authors' own elaboration

showed that the Nigerian cocoa export follows the Linder hypothesis. Similarly, SHAHRIAR et al. (2019a) also reported a negative coefficient of per capita GDP for China and its meat importing countries. In contrast, RASOULINEZHAD et al. (2020) revealed that Russia's export pattern with the East Asian region did not follow the Linder hypothesis, in other words, it follows the Heckscher-

Table 3 - Descriptive statistics of the variables used in the study.

\begin{tabular}{lccccc}
\hline Variables & Mean & Standard Deviation & Minimum & Maximum & Observations \\
\hline CocoaExp $_{i j t}$ & $17,574.5100$ & $49,814.5400$ & 0.002 & $666,116.40$ & 634 \\
$\ln \left(G D P_{i t} \cdot G D P_{j t}\right)$ & 51.8503 & 2.5900 & 45.6163 & 57.5607 & 864 \\
$\ln \left(p c G D P_{i t} \cdot p c G D P_{j t}\right)$ & 23.3995 & 2.6308 & 14.0844 & 31.2749 & 864 \\
$\ln \left(\right.$ dpcGDP $\left._{i j t}\right)$ & 11.6662 & 1.3788 & 3.3584 & 13.3832 & 604 \\
$\ln \left(\right.$ Exc $\left._{i j t}\right)$ & 2.1367 & 3.1026 & -5.1916 & 7.2000 & 864 \\
${\text { ln }\left(\text { Distance }_{i j}\right)}_{\text {landlocked }_{j}}$ & 8.3747 & 0.8187 & 6.4102 & 9.4707 & 864 \\
border $_{i j}$ & 0.1389 & 0.3460 & 0.0000 & 1.0000 & 864 \\
language $_{i j}$ & 0.0833 & 0.2765 & 0.0000 & 1.0000 & 864 \\
WTOm $_{j}$ & 0.2778 & 0.4482 & 0.0000 & 1.0000 & 864 \\
EUm $_{j t}$ & 0.7789 & 0.4152 & 0.0000 & 1.0000 & 864 \\
Aum $_{j t}$ & 0.3137 & 0.4642 & 0.0000 & 1.0000 & 864 \\
Ecowas $_{j}$ & 0.2500 & 0.4333 & 0.0000 & 1.0000 & 864 \\
asia $_{j}$ & 0.1111 & 0.3145 & 0.0000 & 1.0000 & 864 \\
colony $_{i j}$ & 0.2778 & 0.4481 & 0.0000 & 1.0000 & 864 \\
\hline
\end{tabular}

Source: Authors' own elaboration.

Ciência Rural, v.51, n.11, 2021. 
Table 4 - The estimated coefficients from Heckman selection models.

\begin{tabular}{|c|c|c|c|c|c|c|c|c|}
\hline \multirow[t]{2}{*}{ Variables } & \multicolumn{4}{|c|}{--------------------------------Main----------------------------- } & \multicolumn{4}{|c|}{------------------------------Selection----------------------- } \\
\hline & Coefficient & & Std. Dev. & $\mathrm{P}|>| \mathrm{z}$ & Coefficient & & Std. Dev. & $\mathrm{P}|>| \mathrm{z}$ \\
\hline $\ln \left(G P_{i t} \cdot G D P_{j t}\right)$ & 0.3172 & *** & 0.0712 & 0.0000 & 0.3689 & *** & 0.0748 & 0.0000 \\
\hline $\ln \left(p_{c G D P} \cdot p_{i t} \operatorname{pGDP}_{\mathrm{jt}}\right)$ & -0.1569 & & 0.0992 & 0.1140 & -0.9083 & & 0.0607 & 0.1340 \\
\hline $\ln \left(\mathrm{dpcGDP}_{\mathrm{ijt}}\right)$ & -0.0428 & & 0.0976 & 0.6610 & -0.0380 & & 0.0829 & 0.6470 \\
\hline $\ln \left(\mathrm{Exc}_{\mathrm{ijt}}\right)$ & 0.1861 & ** & 0.0822 & 0.0240 & 0.2253 & $* * *$ & 0.0520 & 0.0000 \\
\hline $\ln \left(\right.$ Distance $\left._{\mathrm{ij}}\right)$ & -0.1553 & & 0.3373 & 0.6450 & -0.5758 & & 0.3949 & 0.1450 \\
\hline landlocked $_{j}$ & -2.1566 & $* * *$ & 0.3775 & 0.0000 & -0.8827 & $* * *$ & 0.3282 & 0.0070 \\
\hline border $_{i j}$ & -1.6477 & $*$ & 0.9132 & 0.0710 & 4.3685 & $* * *$ & 0.8594 & 0.0000 \\
\hline language $_{i j}$ & 0.0024 & & 0.2673 & 0.9930 & 0.0899 & & 0.3656 & 0.8060 \\
\hline $\mathrm{WTOm}_{\mathrm{j}}$ & 1.3315 & $* * *$ & 0.3311 & 0.0000 & 0.7830 & $* *$ & 0.3263 & 0.0160 \\
\hline $\mathrm{EUm}_{\mathrm{jt}}$ & 0.6714 & ** & 0.2739 & 0.0140 & 0.1297 & & 0.2409 & 0.5900 \\
\hline Aum $_{j t}$ & -2.3323 & $* * *$ & 0.4987 & 0.0000 & -1.0397 & $* *$ & 0.4881 & 0.0330 \\
\hline Ecowas $_{\mathrm{j}}$ & & & & & -1.9477 & $* * *$ & 0.6857 & 0.0050 \\
\hline $\operatorname{asia}_{j}$ & & & & & -1.7293 & $* * *$ & 0.3327 & 0.0000 \\
\hline colony $_{\mathrm{ij}}$ & & & & & 1.2733 & ${ }^{* * *}$ & 0.4767 & 0.0080 \\
\hline constant & -5.1387 & & 3.7712 & 0.1730 & -10.4014 & ** & 4.2168 & 0.0140 \\
\hline athrho & & & & & -0.0665 & & 1.1723 & 0.6990 \\
\hline insigma & & & & & 0.6919 & $* * *$ & 0.0318 & 0.0000 \\
\hline log-likelihood & & & & & ---------------------- & --12 & 01--------- & ----------- \\
\hline No. of observations & & & & & --------------------- & $---\cdot-$ & ------------.- & --------- \\
\hline wald chi & & & & & -------------------- & $----\cdot$ & .58---------- & -------- \\
\hline Pro $>c h$ & & & & & 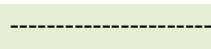 & ----0 & $0^{* * *}$ & - \\
\hline
\end{tabular}

Source: Authors' own estimations. Note: ${ }^{* * *},{ }^{* *}$, and ${ }^{*}$ indicates significant at $1 \%, 5 \%$ and $10 \%$ respectively.

Ohlin hypothesis. Besides, the negative sign can be attributed to the rapid economic growth in Nigeria as well as the accelerated increase in population which reached nearly $20 \%$ increases in the last decade. This indicated that the $1 \%$ increase per capita of $\mathrm{i}$ and $\mathrm{j}$ countries cause cocoa exports to decrease by $0.31 \%$. It also points out that the Nigerian cocoa export patterns follow a GDP pattern, focusing on the production and export of quantity-based products and reliant on total market size, rather than a per capita GDP pattern addressing the export of quality-based high value-added products which can be easily affected to the levels of income. In the traditional gravity model GDP usually signifies income.

The distance $\left(\right.$ Distance $\left._{i t}\right)$ between Nigeria's capital and its trading partner's capital is taken as a proxy for trade costs. In our PPML and GLS models distance was significant at $1 \%$ and $10 \%$ with negative coefficients respectively whereas, in the Heckman model is insignificance also with negative coefficients. This showed that the distance between Abuja to the capitals of importing countries decreases cocoa trade flows by $1.29 \%$. BRAHA et al. (2017) disclose a similar result for Albania and its trading partners. LIU et al. (2020) and NASRULLAH et al. (2020) reported that China's exports are hindered by both institutional and cultural distance. Additionally, our result is in line with the classical findings of the gravity model.

Furthermore, the coefficients of the bilateral exchange rate $\left(E x c_{i j \mathrm{j}}\right)$ between "Naira" and importing countries' currency are positively significant at $1 \%$ and $5 \%$ only in the Heckman models. In other words, a depreciation of the Nigerian currency ( $\mathrm{N}$ ) results in a nearly $0.21 \%$ increase in cocoa export flows. The result is in line with several prior studies conducted by IRSHAD et al. (2018) and JORDAAN \& EITA (2012). At the same time, IGUE \& OGUNLEYE (2014) proposed that a decrease in the price of the Nigerian currency "Naira" has a positive effect on the trade balance in the long run. They also reported that a $1 \%$ reduction in the value of "Naira" would improve trade balance by $1.16 \%$. Since the collapse of the Bretton Woods system of fixed exchange rates 
Table 5 - The estimated coefficients from GLS and PPML models.

\begin{tabular}{|c|c|c|c|c|c|c|c|c|}
\hline \multirow[t]{2}{*}{ Variables } & \multicolumn{4}{|c|}{------------------------------GLS---------------------------- } & \multicolumn{4}{|c|}{----------------------------PPML--------------------------' } \\
\hline & -------Coeffic & ------ & Std. Dev. & $\mathrm{P}|>| \mathrm{z}$ & --------Coeffi & ----- & Std. Dev. & $\mathrm{P}|>| \mathrm{z}$ \\
\hline $\ln \left(G D P_{i t} \cdot G D P_{j t}\right)$ & 0.4831 & $* * *$ & 0.1750 & 0.006 & 0.1564 & $* * *$ & 0.0383 & 0.000 \\
\hline $\ln \left(p c G D P_{i t} \cdot p c G D P_{j t}\right)$ & -0.3601 & ** & 0.1610 & 0.025 & -0.2661 & * & 0.1439 & 0.064 \\
\hline $\ln \left(d p c G D P_{i j t}\right)$ & 0.1306 & & 0.1243 & 0.293 & -0.1110 & & 0.1547 & 0.473 \\
\hline $\ln \left(E x c_{i j t}\right)$ & 0.0326 & & 0.7943 & 0.850 & 0.2526 & & 0.2269 & 0.266 \\
\hline $\ln \left(\right.$ Distance $\left._{i j}\right)$ & -1.3623 & * & 0.7943 & 0.086 & -1.2212 & $* * *$ & 0.3721 & 0.001 \\
\hline landlocked $_{j}$ & -2.7482 & ** & 1.1324 & 0.015 & -2.8894 & $* * *$ & 0.3100 & 0.000 \\
\hline border $_{i j}$ & -3.0437 & & 2.3681 & 0.199 & 2.1470 & * & 1.2707 & 0.091 \\
\hline language $_{i j}$ & -0.6315 & & 0.7904 & 0.428 & -0.5016 & * & 0.2589 & 0.053 \\
\hline$W_{T O m_{j}}$ & 1.7006 & *** & 0.4836 & 0.000 & 2.0116 & $* * *$ & 0.4515 & 0.000 \\
\hline$E U m_{j t}$ & 1.7115 & $* * *$ & 0.4330 & 0.000 & 1.8116 & $* * *$ & 0.3854 & 0.000 \\
\hline $\mathrm{Aum}_{j t}$ & -3.8838 & $* * *$ & 1.3384 & 0.004 & -0.6157 & & 0.7239 & 0.395 \\
\hline constant & 0.6826 & & 9.1838 & 0.941 & -17.7098 & $* * *$ & 5.0534 & 0.000 \\
\hline$R^{2}$ & \multicolumn{4}{|c|}{-----------------------------0.6599--------------------------- } & \multicolumn{4}{|c|}{------------------------------0.2479------------------------' } \\
\hline No. of observations & \multicolumn{4}{|c|}{--------------------------------499------------------------------ } & \multicolumn{4}{|c|}{----------------------------------499--------------------------- } \\
\hline log-likelihood & & & & & \multicolumn{4}{|c|}{ 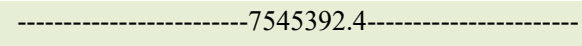 } \\
\hline
\end{tabular}

Source: Authors' own estimations. Note: ${ }^{* * *},{ }^{* *}$, and ${ }^{*}$ indicates significant at $1 \%, 5 \%$ and $10 \%$ respectively.

in the early 1970 s, the high degree of volatility and uncertainty of exchange rate movements. Several prior studies have generated theoretical and empirical evidence to determine the effect of exchange rate vitality on Nigerian exports (ONAFOWORA \& OWOYE, 2008; ALIYU, 2010). Moreover, ADDAI et al. (2020) explored the international cocoa exports and exchange rate regimes and claimed that the profits gained from the cocoa exports had been wiped out by the inflexibility of the exchange rate. The analysts also suggested adopting a more flexible exchange rate policy on the part of the cocoa-producing countries.

Additionally, a landlocked (Landlocked) situation as a variable is reported to be highly significant at $1 \%$ in the PPML, Heckman selection, and main models and at 5\% in the GLS model all with negative coefficients. This shows that landlocked decreases Nigerian cocoa exports by nearly $2.42 \%$. PAUDEL \& COORAY (2018) disclose that the export performance of landlocked developing nations is low due to the inherent additional costs related to being a landlocked country. A nation's comparative benefit in trade is affected by its trade costs and trade composition (MILNER \& MCGOWAN, 2013).

Border $\left(\right.$ border $\left._{i j}\right)$ form local business systems and patterns of agglomeration, which in turn shape economic activities. However, our border dummy turns out to be significant in the Heckman models with positive and negative coefficients $(-1.6477,10 \%$ and $4.3685,1 \%)$. The findings suggested that a shared and common border could promote the exports of cocoa products by $4.36 \%$ or decrease the flow by $1.64 \%$. The explanation behind the argument is that Nigeria shares borders with four countries Benin, Cameroon, Chad, and Niger; however, Cameroon and Chad also share a common border. Considering the fact that Cameroon is also among the top four exporters of cocoa from Africa after Ivory Coast, Ghana, and Nigeria, this creates competition in cocoa exports between Nigeria and Cameroon along Chad's borders. A common language (language $_{i j}$ ) is significant only at $10 \%$ in the PPML model with a negative coefficient. This indicated that sharing a common language with an importing partner decrease export by $0.50 \%$. The result contradicted prior studies that report language as a tool for networks, communications, and promotes export (ATIF et al., 2016; CASTILLO et al., 2016).

The WTOm $_{j t}$ membership is highly significant at $1 \%$ in all models except in the selection model at $5 \%$ with positive coefficients. Nigerian has been active in the world cocoa market which makes it a key exporting nation in the world. Results in Tables 4 and 5 show that WTO promotes exports of Nigerian cocoa by $1.46 \%$. This implies that WTO membership did influence cocoa exports from Nigeria. The 
previous studies of gravity analysis of Bangladesh textile exports carried out by RAHMAN et al. (2019) and Cambodian export performance conducted by SOENG \& CUYVERS (2017) also provide empirical evidence to support the significance of WTO membership in export.

The results further showed that the EU is the biggest destination for the Nigerian cocoa. The $E U m_{j t}$ dummy variable is highly significant at $1 \%$ with positive coefficients in the GLS and PPML models and 5\% in the Heckman main model. The result is consistent with the finding of KEA et al. (2019) who reported a positive effect of the EU membership on the Cambodian rice trade. According to COULIBALY \& ERBAO, (2019) cocoa production in Africa in general and West Africa in particular was initially meant to satisfy the European market demand. The AU is strongly significant at $1 \%$ in Heckman and GLS model with negative coefficients but insignificant in PPML. This indicated that AU has an inverse effect on the Nigerian export. This might be due to the fact that many African countries, such as the Ivory Coast, Ghana, Cameroon, Tanzania, Togo, Democratic Republic of Congo, and Uganda, are among major producers of cocoa and had the negative impacts on the cocoa export in Nigeria.

Similarly, three variables were added to the selection equation eq.6: Ecowas , $_{\mathrm{i}}$ sia $_{j}$ and common colony $\left(\right.$ colony $\left._{i j}\right)$. The ECOWAS membership is significant at $1 \%$ but with a negative coefficient. In other words, its decrease cocoa export flows by $1.95 \%$. We expected this result because West Africa is the most important region in the world in terms of cocoa production (WESSEL \& QUIST-WESSEL, 2015). Ivory Coast and Ghana are the two biggest producers and exporters, but Nigeria is the fourth largest producer and 5th largest exporter. Moreover, countries like Togo and Sierra Leone are also cocoaproducing countries. Similarly, as pointed out in the previous literature that export between ECOWAS members may be a bad idea and the failure of ECOWAS countries to boost bilateral trade among it 15 member states is contributed by the restrictive trade policies and weak institutions (ASSANE \& CHIANG, 2014).

The geographical dummy $($ asia $)$ is negative $(-1.73)$ but strongly significant at $1 \%$. This indicated that the Nigerian cocoa trade decrease by $1.73 \%$ with the Asian countries. BUI \& CHEN (2015) reported a similar result between Vietnam and its rice importing partners. Conversely, a common colony is significant at $1 \%$, meaning that Nigeria would share the same colonial heritage and economic practices with its importing country. As a result, the export value will increase by $1.27 \%$. Prior studies such as ATIF et al. (2016) and JOMIT (2015) also find similar results.

\section{CONCLUSION}

This paper has attempted to identify the major factors affecting Nigerian cocoa exports using the gravity model. In line with the theoretical and empirical studies, the study is based on the application of the three different analytical approaches including the Heckman selection models, GLS and PPML. The authors run these models to overcome the problems of the multi-collinearity, serial correlation, heteroscedasticity, zero trade, for comparative purpose. The analysis is based on a panel dataset from 1995 to 2018 ( 24 years) for a total of 36 selected largest cocoa importing partners. The study is a novel research in the sense that Nigeria's main trading partners are covered in the sampling framework. Also, a commodity-specific gravity modelling is attempted for Nigeria's cocoa export sector and we aimed to fill a gap on the Nigerian agricultural trade.

The study generated a number of interesting findings and insights. First, The EU countries Netherland, Germany, France, etc., and the USA, Canada, and Malaysia are the most important market for Nigerian cocoa exports. Second, the GDP, WTO, EU, and common colony are the positive determinants of Nigerian cocoa export flows. Also, the positive impact of exchange rate policy is observed. Third, the per capita GDP (pcGDP), distance, landlocked, AU, ECOWAS, and Asia are the negative factors associated with the Nigerian cocoa export flows.

We are now in a position to offer a few recommendations for the development of the Nigerian cocoa exports. First, the FRN would continue to build up strong bilateral relations with the current cocoa trading partners by employing trade promotion policies and other trade promotion tools such as bilateral trading agreements. Second, the FRN could facilitate its cocoa exports by giving less attention to AU and ECOWAS countries. Third, a suitable and gradual devaluation of 'Naira' couple with an export policy that encourages cocoa production is required to improve cocoa export revenue. Fourth, future researchers may examine other agricultural products of Nigeria to extend the current results. The researchers could also include both agricultural-commodities imports and export equations altogether in a single study. Further research efforts can focus on a comparison of the methodology presented in this article with SFA results that uses the maximum possible value of trade 
rather than average values to infer on the inefficiency and the trade potential of the country.

\section{ACKNOWLEDGMENTS}

This paper was supported by the Earmarked Fund for China Agricultural Research System (Grant Number, CARS-28).

\section{DECLARATION OF CONFLICT OF INTEREST}

The authors declare no conflict of interest. The founding sponsors had no role in the design of the study; in the collection, analyses, or interpretation of data; in the writing of the manuscript, and in the decision to publish the results.

\section{AUTHORS' CONTRIBUTIONS}

All authors contributed equally for the conception and writing of the manuscript. All authors critically revised the manuscript and approved of the final version.

\section{REFERENCES}

ADDAI, B., et al. Exchange rate regimes and global cocoa trade: To float or to peg? Cogent Economics \& Finance, v.8, n.1. 2020. Available from: <https://www.tandfonline.com/doi/full/10 $.1080 / 23322039.2020 .1719593>$. Accessed: Sep. 20, 2020. doi: $10.1080 / 23322039.2020 .1719593$.

ADELEYE, N.,etal.Agro-industrialisation andfinancialintermediation in Nigeria. African Journal of Economic and Management Studies, v.11, n3, 2020. Available from: <https:/www.emerald.com/insight/ content/doi/10.1108/AJEMS-02-2019-0078/full/html $>$. Accessed: Sep. 20, 2020. doi: 10.1108/ajems-02-2019-0078.

ALI, I., et al. The impact of agriculture trade and exchange rate on economic growth of Pakistan: An NARDL and asymmetric analysis approach. Ciência Rural, v.50, n.4, p.e20190005. 2020. Available from: <https://doi.org/10.1590/0103-8478cr20190005>. Accessed: Sep. 20, 2020. doi: 10.1590/0103-8478cr20190005.

ALIYU, S. U. R.; BAWA, S. Gravity model by panel data approach: Empirical evidence from Nigeria. Inernational Journal of Trade and Global Markets, vol.8 no.1. p.42-57. 2015. Available from: <https://www.inderscienceonline.com/doi/ pdf/10.1504/IJTGM.2015.067972>. Accessed: Jun. 12, 2020. doi: 10.1504/IJTGM.2015.067972.

ALIYU, S. U. R. Exchange rate volatility and export trade in Nigeria An empirical investigation. Applied Financial Economics, v.20, n.13, p.1071-1084. 2010. Available from: <https://www. tandfonline.com/doi/abs/10.1080/09603101003724380>. Accessed: Jun. 12, 2020. doi: 10.1080/09603101003724380.

AMEMIYA, T. Selection of regressors. International Economic Review, v.21, n.2, p.331-354. 1980. Available from: <https:/ www.jstor.org/stable/2526185>. Accessed: Jun. 12, 2020. doi: $10.2307 / 2526185$.

ANDERSON, J. E. A theoretical foundation for the gravity equation. The American Economic Review, v.69, n.1, p.106-116.
1979. Available from: <https://www.jstor.org/stable/1802501>. Accessed: Jun. 12, 2020.

ANDERSON, J. E.; Wincoop, E. Gravity with gravitas: A solution to the border puzzel American Economic Review, v.93, n.1, p.170-192. 2003. Available from: <https://www. jstor.org/stable/3132167>. Accessed: Jun. 12, 2020. doi: $10.125 / 0002803321455214$.

ANH THU, L., et al. Factors influencing Vietnam's handicraft export with the gravity model. Journal of Economics and Development, v.21, n.2, p.156-171. 2019. Available from: $<$ https://www.emerald.com/insight/content/doi/10.1108/JED-082019-0021/full/pdf?title=factors-influencing-vietnams-handicraftexport-with-the-gravity-model $>$. Accessed: Jul. 12, 2020. doi: 10.1108/jed-08-2019-0021.

ASSANE, D.; CHIANG, E. P. Trade, structural reform, and institutions in Sub-Saharan Africa. Contemporary Economic Policy, v.32, n.1, p.20-29. 2014. Available from: <https://onlinelibrary.wiley. com/doi/epdf/10.1111/j.1465-7287.2012.00338.x>. Accessed: Sep. 10, 2020. doi: 10.1111/j.1465-7287.2012.00338.x.

ATIF, R. M., et al. Pakistan's agricultural exports, determinants and its potential: An application of stochastic frontier gravity model. The Journal of International Trade \& Economic Development, v.26, n.3, p.257-276. 2016. Available from: <https://www. tandfonline.com/doi/abs/10.1080/09638199.2016.1243724>. Accessed: Jan. 11, 2020. doi: 10.1080/09638199.2016.1243724.

BALTAGI, B. H., et al. Generalized spatial autocorrelation in a panel-probit model with an application to exporting in China. Empirical Economics, v.55, n.1, p.193-211. 2018. Available from: $<$ https://link.springer.com/article/10.1007/s00181-017-1409-0>. Accessed: Feb. 18, 2020. doi: 10.1007/s00181-017-1409-0.

BERA, A. K.; C. M. JARQUE. Model specification tests: A simultaneous approach. Journal of Econometrics, v.20, n.59-82. 1982. Available from: <https://www.sciencedirect.com/science/ article/pii/0304407682901038>. Accessed: Aug. 20, 2019. doi: 10.1016/0304-4076(82)90103-8.

BERGSTRAND, J. H. The generalized gravity equation, monopolistic competition, and the factor-proportions theory in international trade. The Review of Economics and Statistics, v.71, n.1, p.143-153. 1989. Available from: <https:// doi.org/10.2307/1928061>. Accessed: Jan. 18, 2020. doi: $10.2307 / 1928061$.

BERGSTRAND, J. H. The Heckscher-Ohlin-Samuelson model, the Linder Hypothesis and the determinants of bilateral intraindustry trade. The Economic Journal, v.100, n.403, p.12161229. 1990. Available from: <https://doi.org/10.2307/2233969>. Accessed: Jan. 11, 2020. doi: 10.2307/2233969.

BOEREMA, A., et al. Soybean trade: Balancing environmental and socio-economic impacts of an intercontinental market. PLoS One, v.11, n.5, p.e0155222. 2016. Available from: <https://www. ncbi.nlm.nih.gov/pubmed/27244079>. Accessed: Jun. 12, 2020. doi: 10.1371/journal.pone.0155222.

BRAHA, K., et al. Determinants of Albanian agricultural export: The gravity model approach. Agris on-line Papers in Economics and Informatics, v.8, n.2, p.3-21. 2017. Available from: <https:// online.agris.cz/archive/2017/02/01>. Accessed: Jan. 11, 2019. doi: 10.7160/aol.2017.090201. 
BUI, T. H. H.; Q. CHEN. An analysis of factors influencing rice export in Vietnam based on gravity model. Journal of the Knowledge Economy, v.8, n.3, p.830-844. 2015. Available from: $<$ https://link.springer.com/article/10.1007/s13132-015-0279-y>. Accessed: Jan. 11, 2019. doi: 10.1007/s13132-015-0279-y.

BURGER, M., et al. On the specification of the gravity model of trade: Zeros, excess zeros and zero-inflated estimation. Spatial Economic Analysis, v.4, n.2, p.167-190. 2009. Available from: $<$ https://www. tandfonline.com/doi/abs/10.1080/17421770902834327>. Accessed: Jan. 11, 2020. doi: 10.1080/17421770902834327.

CASTILLO, J. S., et al. The international wine trade and its new export dynamics (1988-2012): A gravity model approach. Agribusiness, v.32, n.4, p.466-481. 2016. Available from: $<$ https:// onlinelibrary.wiley.com/doi/abs/10.1002/agr.21463>. Accessed: Jan. 20, 2020. doi: 10.1002/agr.21463.

CHANEY, T. Distorted gravity: The intensive and extensive margins of international trade. American Economic Review, v.98, n.4, p.1707-1721. 2008. Available from: <https://www.aeaweb. org/articles?id=10.1257/aer.98.4.1707>. Accessed: Jan. 20, 2019. doi: 10.1257/aer.98.4.1707.

CHANEY, T. The gravity equation in international trade: An explanation. Journal of Political Economy, v.126, n.1, p.77-150. 2018. Available from: $<$ https://www.journals.uchicago.edu/doi/abs $/ 10.1086 / 694292$ ?journalCode $=$ jpe $>$. Accessed: Jan. 20, 2019. doi: $10.1086 / 694292$

COULIBALY, S. K.; C. ERBAO. An empirical analysis of the determinants of cocoa production in Cote d'Ivoire. Journal of Economic Structures, v.8, n.1. 2019. Available from: <link. springer.com/article/10.1186/s40008-019-0135-5>. Accessed: Jan. 20, 2020. doi: 10.1186/s40008-019-0135-5.

DADAKAS, D., et al. Examining the trade potential of the UAE using a gravity model and a poisson pseudo maximum likelihood estimator. The Journal of International Trade \& Economic Development, p.1-28. 2020. Available from: <https://www. tandfonline.com/doi/abs/10.1080/09638199.2019.1710551>. Accessed: Sep. 20, 2020. doi: 10.1080/09638199.2019.1710551.

DEARDORFF, A. V. Determinants of bilateral trade: Does gravity work in a neoclassical world? . In: J. A. Frankel (Ed.). The Regionalization of the World Economy. Chicago and London: University of Chicago Press, 1998. Determinants of bilateral trade: Does gravity work in a neoclassical world?

DONG, C. V.; H. Q. TRUONG. The determinants of creative goods exports: Evidence from Vietnam. Journal of Cultural Economics, v.44, n.2, p.281-308. 2019. Available from: <https://link.springer. com/article/10.1007/s10824-019-09359-y>. Accessed: Jan. 11, 2020. doi: 10.1007/s10824-019-09359-y.

EGGER, P. An econometric view on the estimation of gravity models and the calculation of trade potentials. The world Bank, v.25, n.2, p.297-312. 2002. Available from: <https://onlinelibrary. wiley.com/doi/10.1111/1467-9701.00432>. Accessed: Jan. 11, 2019. doi: $10.1111 / 1467-9701.00432$

FAGBADEBO, O. M. Introduction: An overview of democratic practice and governance. In: E. O. Oni, O. M. Fagbadebo, et al (Ed.). Democratic practice and governance in Nigeria. London and New York: Taylor and Francis Group, 2020. Introduction: An overview of democratic practice and governance
FAMUYIWA, B. S., et al. Preventive Measures Adopted by Nigerian Farmers for the Environmental Hazards in Cocoa Plantations. Journal of Agricultural Extension, v.18, n.2, p.99111. 2014. Available from: <https://www.ajol.info/index.php/jae/ article/view/110463>. Accessed: Jan. 11, 2019. doi: 10.4314/jae. v18i2.11.

FAOSTAT. Data center for the food and agriculture organization of the United Nations. Rome, Italy 2020

HAQ, Z. U., et al. Selection bias in a gravity model of agrifood trade. European Review of Agricultural Economics, v.40, n.2, p.331-360. 2013. Available from: <https://journals.sagepub.com/ doi/10.1177/2319714519872643>. Accessed: Sep. 20, 2020. doi: 10.1093/erae/jbs028.

HEAD, K.; T. MAYER. Gravity equations: Workhorse,toolkit, and cookbook. In: E. Helpman e K. Rogoff (Ed.). Handbook of international economics,. AE Amsterdam, The Netherlands: North-Holland: Elsevier, v.4, 2014. Gravity equations: Workhorse,toolkit, and cookbook, p.131-195

HECKMAN, J. J. Sample selection bias as a specification error. Econometrica, v.47, n.1, p.61-153. 1979. Available from: $<$ https:// www.jstor.org/stable/1912352>. Accessed: Jan. 11, 2020. doi: $10.2307 / 1912352$

HELPMAN, E.; P. KRUGMAN. Market Structure and Foreign Trade: Increasing Returns, Imperfect Competition, and the International Economy. MIT Press Books: The MIT Press. 1987

HELPMAN, E., et al. Estimating trade flows: Trading partners and trading volumes. The quarterly journal of economics, v.123, n.2, p.441-484. 2008. Available from: <https://dash.harvard.edu/ bitstream/handle/1/3228230/melitz estimatingtradeflows.pdf $>$. Accessed: Apr. 14, 2018. doi: 10.1162/qjec.2008.123.2.441.

HOANG, N. T. T., TRUONG, H. Q., \& VAN DONG, C. Determinants of trade between Taiwan and Asean countries: A PPML estimator approach. SAGE Open, Vol. 10, no.2, p.215824402091951. 2020. Available from: <https://journals. sagepub.com/doi/pdf/10.1177/2158244020919516>. Accessed: Jan. $14, \quad 2021$. doi: 10.1162/qjec.2008.123.2.441.doi: $10.1177 / 2158244020919516$.

ICCO. Annual Report 2014-2015. Abidjan, Côte d'Ivoire: International Cocoa Organization 2017.

IGUE, N. N.; T. S. OGUNLEYE. Impact of real exchange rate on trade balance in Nigeria. African Development Review, v.26, n.2, p.347-358. 2014. Available from: <https://onlinelibrary.wiley. com/doi/full/10.1111/1467-8268.12086> Accessed: Apr. 20, 2018. doi: $10.1111 / 1467-8268.12086$.

IRSHAD, M. S., et al. Competitiveness of Pakistani rice in international market and export potential with global world: A panel gravity approach. Cogent Economics \& Finance, v.6, n.1, p.1486690. 2018. Available from: <https://www.tandfonline.com/ doi/full/10.1080/23322039.2018.1486690>. Accessed: Jun. 11, 2020. doi: $10.1080 / 23322039.2018 .1486690$.

JOMIT, C. P. Export potential of environmental goods in India: A gravity model analysis. Transnational Corporations Review, v.6, n.2, p.115-131. 2015. Available: <https://www.tandfonline. com/doi/abs/10.1080/19186444.2014.11658386> Accessed: Jul. 16, 2020. doi: 10.1080/19186444.2014.11658386. 
JORDAAN, A. C.; J. H. EITA. Determinants of South Africa's exports of leather products. Agrekon, v.51, n.2, p.38-52. 2012. Available from: <https://www.tandfonline.com/doi/abs/10.1 080/03031853.2012.695137>. Accessed: Jul. 21, 2020. doi: $10.1080 / 03031853.2012 .695137$.

KEA, S., et al. Factors influencing Cambodian rice exports: An application of the dynamic panel gravity model. Emerging Markets Finance and Trade, v.55, n.15, p.1-22. 2019. Available from: <https://www.tandfonline.com/doi/abs/10.10 80/1540496X.2019.1673724>. Accessed: Feb. 12, 2020. doi: 10.1080/1540496x.2019.1673724.

LIU, A., et al. The roles of cultural and institutional distance in international trade: Evidence from China's trade with the belt and road countries. China Economic Review, v.61, p.101234. 2020. Available from: <https://www.sciencedirect.com/science/article/ abs/pii/S1043951X1830138X>. Accessed: Jul. 20, 2020. doi: 10.1016/j.chieco.2018.10.001.

MA'TYA'S, L. Proper econometric specification of the gravity model. The World Economy, v.21, n.3, p.397-401. 1998. Available from: <https://onlinelibrary.wiley.com/doi/ abs/10.1111/1467-9701.00074>. Accessed: Apr. 14, 2019. doi: 10.1111/twec.1998.21.1ssue-3

MARTIN, W.; C. S. PHAM. Estimating the gravity model when zero trade flows are frequent and economically determined. Applied Economics, v.52, n.26, p.2766-2779. 2020. Available from: <https://www.tandfonline.com/doi/abs/1 0.1080/00036846.2011.599786>. Accessed: Jul. 20, 2020. doi: 10.1080/00036846.2019.1687838.

MARTÍNEZ-ZARZOSO, I. The log of gravity revisited. Applied Economics, v.45, n.3, p.311-327. 2011. Available from: <https:// www.tandfonline.com/doi/abs/10.1080/00036846.2011.599786> . Accessed: Apr. 14, 2018. doi: 10.1080/00036846.2011.599786.

MBNP. Economic Recovery \& Growth Plan 2017-2020. Abuja, Nigeria: Ministry of Budget \& National Planning 2017.

MILNER, C.; D. MCGOWAN. Trade costs and trade composition. Economic Inquiry, v.51, n.3, p.1886-1902. 2013. Available from: $<$ https://onlinelibrary.wiley.com/doi/abs/10.11 11/j.1465-7295.2012.00496.x>. Accessed: Mar. 13, 2020. doi: 10.1111/j.1465-7295.2012.00496.x.

NASRULLAH, M., et al. Determinants of forest product group trade by gravity model approach: A case study of China. Forest Policy and Economics, v.113, p.102117. 2020. Available from: <https://www.sciencedirect.com/science/article/abs/pii/ S1389934119306094>. Accessed: Sep. 20, 2020. doi: 10.1016/j. forpol.2020.102117.

NEPC. Nigerian Export Promotion Council. Production and market information of promising cocoa. Abuja, Nigeria 2017.

NGUYEN, D. D. Determinants of Vietnam's rice and coffee exports: Using stochastic frontier gravity model. Journal of Asian Business and Economic Studies, v.27, no.4. 2020. Available from: $\quad<$ https://www.emerald.com/insight/content/doi/10.1108/ JABES-05-2020-0054/full/html $>$. Accessed: Sep. 20, 2020. doi: 10.1108/JABES-05-2020-0054.

NSABIMANA, A.; W. T. TIRKASO. Examining coffee export performance in Eastern and Southern African countries: Do bilateral trade relations matter? Agrekon, v.59, n.1, p.46-64. 2019. Available from: <https://www.tandfonline.com/doi/full/1 0.1080/03031853.2019.1631864>. Accessed: Jan. 11, 2020. doi: $10.1080 / 03031853.2019 .1631864$

NWACHUKWU, I. N., et al. Competitiveness and determinants of cocoa export from Nigeria. Report and Opinion, v.2, n.7. 2010. Available from: <http://www.sciencepub.net/report/report0207/08 3470report0207_51_54.pdf>. Accessed: 20 June, 2018.

OLADIPUPO, O.; ADEDOYIN, F. Determinants of bilateral trade flows of Nigeria: An application of the augmented gravity model. 2019. Available from: <SSRN: https://papers.ssrn.com/ sol3/papers.cfm?abstract_id=3439986>. Accessed: Feb. 14, 2021. doi: $10.2139 / \mathrm{SSRN} .3439986$.

OLAIYA, T. A. Examining the Political-Economy of Cocoa Exports in Nigeria. The International Journal of Applied Economics and Finance, v.10, n.1, p.1-13. 2016. Available from: $<$ https://scialert.net/fulltext/?doi=ijaef.2016.1.13>. Accessed: Jun. 30, 2019. doi: 10.3923/ijaef.2016.1.13.

ONAFOWORA, O. A.; O. OWOYE. Exchange rate volatility and export growth in Nigeria. Applied Economics, v.40, n.12, p.15471556. 2008. Available from: <https://www.tandfonline.com/doi/ab s/10.1080/00036840600827676? journalCode $=$ raec20 $>$. Accessed: Jun. 20, 2018. doi: 10.1080/00036840600827676.

OSABOHIEN, R., et al. Agriculture development, employment generation and poverty reduction in West Africa. The Open Agriculture Journal, v.13, n.1, p.82-89. 2019. Available from: <https://benthamopen.com/FULLTEXT/TOASJ-13-82>. Accessed: Jan. 20, 2020. doi: 10.2174/1874331501913010082.

OSABUOHIEN, E. S. Large-Scale Agricultural Land Investments and Local Institutions in Africa: The Nigerian Case. Land Use Policy, v.39, p.155-165. 2014. Available from: <https://www. sciencedirect.com/science/article/abs/pii/S0264837714000477>. Accessed: Jun. 22, 2020. doi: 10.1016/j.landusepol.2014.02.019.

PAUDEL, R. C.; A. COORAY. Export performance of developing countries: Does landlockedness matter? Review of Development Economics, v.22, n.3, p.e36-e62. 2018. Available from: $<$ https:// onlinelibrary.wiley.com/doi/abs/10.1111/rode.12389>. Accessed: Sep. 20, 2020. doi: 10.1111/rode. 12389 .

RAHMAN, R., et al. Determinants of exports: A gravity model analysis of the Bangladeshi textile and clothing industries. FIIB Business Review, v.8, n.3,p.229-244.2019.Available from: $<$ https:// journals.sagepub.com/doi/full/10.1177/2319714519872643>. Accessed: Jan. 11, 2020. doi: 10.1177/2319714519872643.

RASOULINEZHAD, E., et al. Assessment of the trade integration pattern between the Russian Federation and East/Southeast Asian economies using the panel gravity framework. Asian Economic Papers, v.19, n.1, p.1-14. 2020. Available from: <https://www. mitpressjournals.org/doi/abs/10.1162/asep_a 00745>. Accessed: Sep. 20, 2020. doi: 10.1162/asep_a_00745.

SANTOS SILVA, J. M. C.; S. TENREYRO. The log of gravity. The Review of Economics and Statistics, v.88, n.4, p.641-658. 2006. Available from: <https://www.mitpressjournals.org/doi/pdf/10.1162/ rest.88.4.641>. Accessed: Jan. 11, 2020. doi: 10.1162/rest.88.4.641.

SANTOS SILVA, J. M. C.; S. TENREYRO. On the existence of the maximum likelihood estimates in poisson regression. Economics 
Letters, v.107, n.2, p.310-312. 2010. Available from: <https:// www.sciencedirect.com/science/article/pii/S0165176510000832>. Accessed: Jan. 11, 2019. doi: 10.1016/j.econlet.2010.02.020.

SANTOS SILVA, J. M. C.; S. TENREYRO. Further simulation evidence on the performance of the poisson pseudo-maximum likelihood estimator. Economics Letters, v.112, n.2, p.220-222. 2011. Available from: $<\mathrm{https}: / / \mathrm{www}$. sciencedirect.com/science/ article/pii/S0165176511001741>. Accessed: Jan. 11, 2019. doi: 10.1016/j.econlet.2011.05.008.

SHAFIULLAH, M., et al. The role of export composition in export-led growth in Australia and its regions. Economic Analysis and Policy, v.53, p.62-76. 2017. Available from: <https://www. sciencedirect.com/science/article/abs/pii/S0313592616300893>. Accessed: Apr. 14, 2020. doi: 10.1016/j.eap.2016.11.002.

SHAHRIAR, S., et al. Determinants of exports in China's meat industry: A gravity model analysis. Emerging Markets Finance and Trade, v.55, n.11, p.2544-2565. 2019a. Available from: <https://www.tandfonline.com/doi/abs/10.1 080/1540496X.2019.1578647>. Accssed: Jan. 11, 2020. doi: 10.1080/1540496X.2019.1578647.

SHAHRIAR, S., et al. The gravity model of trade: A theoretical perspective. Review of Innovation and Competitiveness : A Journal of Economic and Social Research, v.5, n.1, p.21-42. 2019b. Available from: <https://hrcak.srce.hr/220821>. Accessed: Feb. 20, 2020. doi: 10.32728/ric.

SHEPHERD, B. Mega-regional trade agreements and Asia: An application of structural gravity to goods, services, and value chains. Journal of the Japanese and International Economies, v.51, p.32-42. 2019. Available from: <https://www.sciencedirect. com/science/article/pii/S0889158318300418 > . Accessed: Sep. 11, 2020. doi: 10.1016/j.jjie.2018.10.004

SOENG, R.; L. CUYVERS. Domestic institutions and export performance: Evidence for Cambodia. The Journal of International Trade \& Economic Development, v.27, n.4, p.389408. 2017. Available from: $<$ https://www.tandfonline.com/doi/abs $/ 10.1080 / 09638199.2017 .1386230>$. Accessed: Jul. 12, 2020. doi: 10.1080/09638199.2017.1386230.
TINBERGEN, J. Shaping the world economy. The International Executive, v.5, n.1, p.27-30. 1962. Available from: $<$ https://www. jstor.org/stable/2229041>. Accessed: Jul. 12, 2020. doi: 10.1002/ tie. 5060050113

UNCTAD. Data center of the united nations conference on trade and development. New York and Geneva: United Nations 2020.

UWAGBOE, E. O., et al. Cocoa Farmers Attitude towards Utilisation of Integrated Pest Management in Edo and Ogun States of Nigeria. Journal of Agricultural Extension, v.21, n.1, p.70-82. 2017. Available from: <https://www.ajol.info/index.php/jae/article/ view/150969>. Accessed: Aug. 4, 2020. doi: 10.4314/jae.v21i1.6.

VERTER, N. Cocoa export performance in the world's largest producer. Bulgarian Journal of Agricultural Science, v.22, n.5, p.713-721. 2016. Available from: <http://www.agrojournal. org/22/05-03.pdf>. Accessed: Jul. 14, 2020.

WESSEL, M.; P. M. F. QUIST-WESSEL. Cocoa production in West Africa, a review and analysis of recent developments. NJAS - Wageningen Journal of Life Sciences, v.74-75, p.1-7. 2015. Available from: <https://www.sciencedirect.com/science/article/ pii/S1573521415000160>. Accessed: Jul. 12, 2020. doi: 10.1016/j. njas.2015.09.001.

WOOLDRIDGE, J. M. Econometric Analysis of Cross Section and Panal Data. Cambridge, Massachusetts London, England: The MIT Press. 2002. 741p.

WORLD BANK. Agriculture, Forestry, and Fishing, Value Added (\% of GDP) - Nigeria: World Development Indicators 2020.

YOTOV, Y. V., et al. An advanced guide to trade policy analysis: The structural gravity model. Geneva, Switzerland: United Nations: The World Trade Organization 2016.

ZHOU, L., et al. Avian influenza, non-tariff measures and the poultry exports of China. Australian Journal of Agricultural and Resource Economics, v.63, n.1, p.72-94. 2019. Available from: $\quad<$ https://onlinelibrary.wiley.com/doi/abs/10.1111/14678489.12285>. Accessed: Sep. 20, 2020. doi: 10.1111/14678489.12285 . 
Ciência Rural, Santa Maria, v.52:12, 2022

$10.1590 / 01038478$ crerr20201043

e11043

Erratum

cC) (i)

\section{Erratum}

In the article "Nigeria's cocoa exports: a gravity model approach" published in Ciência

Rural, volume 51, number 11, DOI http://dx.doi.org/10.1590/0103-8478cr20201043.

In the author's where we read:

Qianggiang Zhang

Read:

Qiangqiang Zhang 